\title{
Albright's Hereditary Osteodystrophy Associated with Cerebellar Pilocytic Astrocytoma: Coincidence or Genetic Relationship?
}

\author{
Stephan B. Sobottka ${ }^{a}$ Angela Huebner ${ }^{b}$ Markus Haase ${ }^{a}$ Wiebke Ahrens ${ }^{e}$ \\ Edgar Rupprecht ${ }^{c}$ Hans K. Schackert ${ }^{d}$ Gabriele Schackert ${ }^{a}$ \\ Departments of a Neurosurgery, bediatrics, ${ }^{\mathrm{b} P e d i a t r i c ~ R a d i o l o g y, ~ a n d ~ d ~ S u r g i c a l ~ R e s e a r c h, ~ T e c h n i c a l ~ U n i v e r s i t y ~ o f ~}$ \\ Dresden, and ${ }^{e}$ Department of Pediatrics, University of Lübeck, Germany
}

\section{Key Words}

Albright's hereditary osteodystrophy ·

Pseudohypoparathyroidism • Cerebral glioma · Gs $\alpha$ protein · GNAS1 gene - Mutation analysis

\begin{abstract}
Albright's hereditary osteodystrophy $(\mathrm{AHO})$ is a rare inherited disease characterized by skeletal abnormalities, short stature, and, in some cases, resistance to parathyroid hormone, resulting in pseudohypoparathyroidism (PHP). Heterozygous inactivating mutations of the GNAS1 gene are responsible for reduced activity of the alpha subunit of the $\mathrm{Gs}$ protein $\left(\mathrm{G}_{\mathrm{S} \alpha}\right)$, a protein that mediates hormone signal transduction across cell membranes. $\mathrm{G}_{\mathrm{s} \alpha}$ is also known to have oncogenic potentials, leading to the development of human pituitary tumors and Leydig cell tumors. Here, we report the 1st case, a 3.5-year-old girl, with classic AHO phenotype and PHP type $1 \mathrm{~A}$ associated with a cerebellar pilocytic astrocytoma. Coincidence or genetic relationships of both diseases are discussed according to molecular findings and current literature.
\end{abstract}

Copyright (C) 2001 S. Karger AG, Basel

\section{Introduction}

Albright's hereditary osteodystrophy (AHO; MIM No. 103580) is a rare autosomal dominantly inherited syndrome characterized by short stature, obesity, round face, brachymetaphalangism, subcutaneous ossification, and variable mental retardation [1]. Pseudohypoparathyroidims type IA (PHP IA) in AHO patients results from resistance of target organs to parathyroid hormone (PTH) caused by a deficient alpha subunit of the Gs protein $\left(G_{S \alpha}\right)$ $[2,3]$, a guanosine triphosphate binding protein that couples hormone receptors to the stimulation of adenylate cyclase as a second messenger [4]. In patients with PHP IA, the activity of the $\mathrm{G}_{\mathrm{S} \alpha}$ protein is reduced to $50 \%$ [5] due to heterozygous inactivating mutations in the gene encoding the $\mathrm{G}_{\mathrm{S} \alpha}$ subunit (GNAS1) [6]. In contrast, activating mutations of GNASI have been found in McCuneAlbright syndrome [7], in growth hormone producing pituitary adenoma, and ovarian and testicular Leydig cell tumors, suggesting that it functions as a protooncogene $[8$, 9]. GNAS1 is located at 20q13.2-13.3 [3] and consists of 13 exons encoding a 394 amino acid protein [6]. Here we describe the 1st case of AHO associated with a cerebellar pilocytic astrocytoma in a young child.

\begin{tabular}{ll}
\hline KARGER & ( ) 2001 S. Karger AG, Basel \\
Fax +4161301-0163/01/0554-0196\$17.50/0 \\
$\begin{array}{l}\text { E-Mail karger@karger.ch } \\
\text { www.karger.com }\end{array}$ & $\begin{array}{l}\text { Accessible online at: } \\
\text { www.karger.com/journals/hre }\end{array}$
\end{tabular}

Stephan B. Sobottka, MD

Department of Neurosurgery, Technical University of Dresden, Fetscherstrasse 74 D-01307 Dresden (Germany)

Tel. +49 351458 4166, Fax +49 3514584304

E-Mail stephan.sobottka@mailbox.tu-dresden.de 


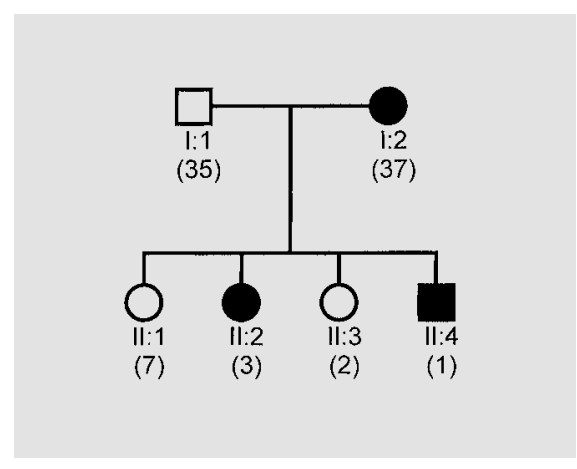

Fig. 1. Pedigree of the family with Albright's hereditary osteodystrophy and PHP IA showing that the disease was maternally inherited affecting two out of four siblings. The index patient II:2 developed a cerebellar astrocytoma.

\section{Case Report}

A 3.5-year-old Caucasian girl was admitted to the Department of Pediatrics after a grand mal seizure. Physical examination revealed typical features of AHO, including short stocky stature (weight $13.1 \mathrm{~kg}$, height $83 \mathrm{~cm}$, height SDS -4.5 ), round face, brachydactyly, cutaneous calcification, and mental retardation. Neurological examination was without focal deficits. Laboratory evaluation revealed hypocalcemia (1.24 mmol/l; normal range 2.08-2.60 mmol/l), hyperphosphatemia $(3.91 \mathrm{mmol} / \mathrm{l}$; normal range $0.87-1.45 \mathrm{mmol} / \mathrm{l})$, and elevated PTH level (991 pg/ml; normal range: $11-54 \mathrm{pg} / \mathrm{ml})$, consistent with the diagnosis of PHP. Serum thyroid-stimulating hormone was elevated $(11.3 \mathrm{mU} / 1$; normal $<4 \mathrm{mU} / \mathrm{l}) ; \mathrm{T}_{3}$ and $\mathrm{T}_{4}$ were within normal limits, providing biochemical evidence of resistance to thyroid-stimulating hormone. The urinary cyclic adenosine monophosphate excretion was in the lower normal range. Adrenocorticotropin, growth hormone, prolactin, cortisol, luteinizing hormone, insulinlike growth factor 1 , and insulin-like growth factor binding protein 3 were within normal limits. Follicle-stimulating hormone was elevated (8.8 U/1; normal range $<0.5-3.2 \mathrm{U} / 1)$. A 1-year-old brother of our index patient also exhibited AHO with PHP IA. Their mother had AHO with pseudopseudohypoparathyroidism. The father and two sisters demonstrated no abnormal findings (fig. 1).

Radiological examinations of the girl revealed cutaneous calcification at the medial malleolus of the left foot, frontal hyperostosis, coxa valga, brachydactyly of hands and feet, caudal narrowing of the lumbar spinal canal, and osteoporotic signs on chest X-ray. Cerebral MRI demonstrated a well-circumscribed lesion with a diameter of $3 \mathrm{~cm}$ in the fourth ventricle (fig. 2a). On CT scan, there was evidence of intracranial calcifications of the basal ganglia. The intracerebellar mass was explored through a medial suboccipital approach to the fourth ventricle. The tumor could easily be separated from the adjacent brain and was completely removed (fig. 2b). Postoperatively, the patient was without neurological deficits and showed an unremarkable course. Histopathological examination revealed a pilocytic astrocytoma (WHO grade I) with frequent microcysts and complete absence of anaplasia.

Albright's Hereditary Osteodystrophy and Cerebellar Astrocytoma
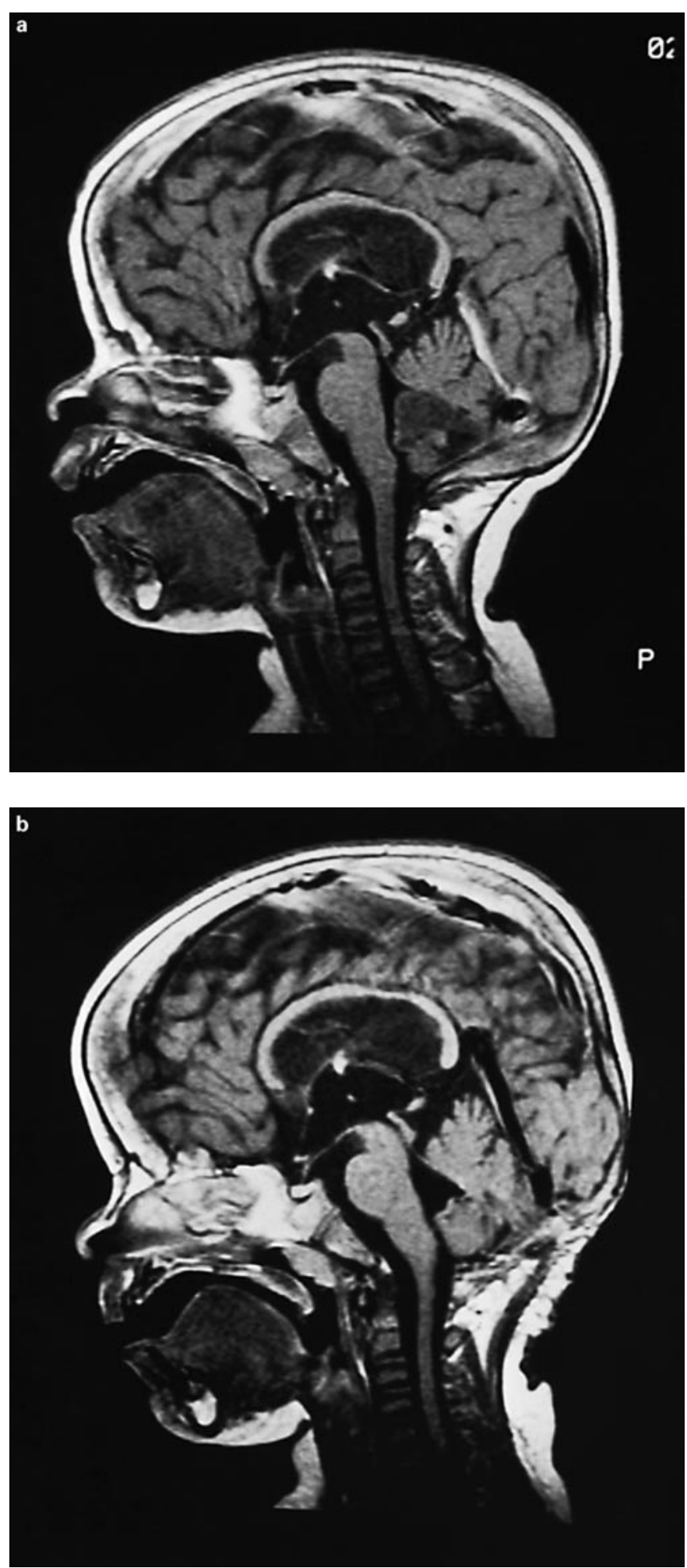

Fig. 2. a T1-weighted MRI with gadolinium shows a well-demarcated vermian lesion within the fourth ventricle. b Postoperative T1weighted MRI with gadolinium confirming complete tumor removal. 


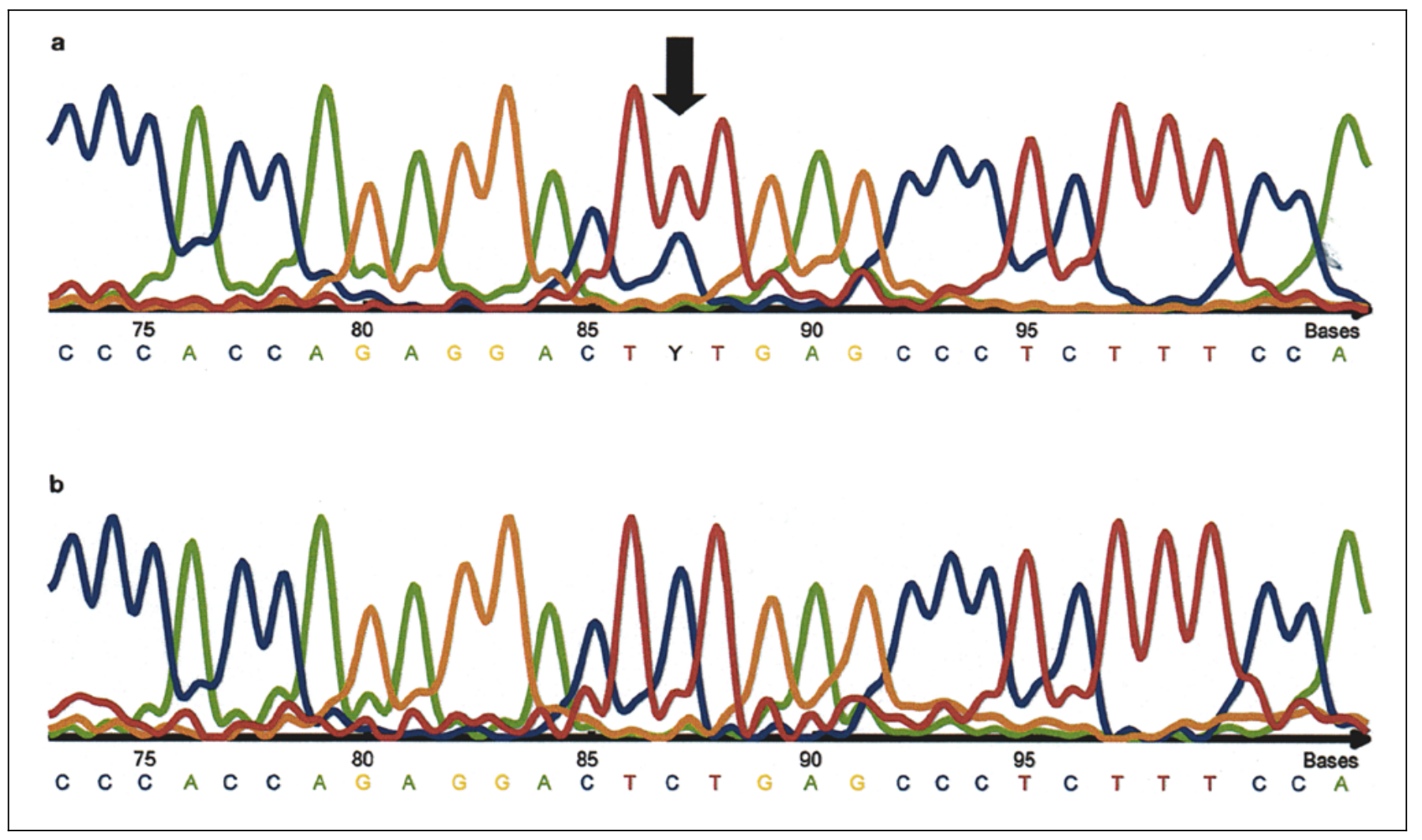

Fig. 3. All 3 AHO-affected family members carried a heterozygous C-to-T transition $30 \mathrm{bp}$ upstream from the $5^{\prime}$ splice site of intron 7 in the germline (a). In contrast, all 3 non-affected family members as well as 103 control individuals demonstrated the wild-type sequence only $(\mathbf{b})$.

\section{Methods}

\section{DNA Extraction, PCR, and Sequence Analysis}

For molecular analysis, genomic DNA extracted from peripheral blood leukocytes of all 6 family members including the index patient was screened for germline mutations of the GNAS1 gene. In addition, DNA was extracted from snap-frozen tissue of the cerebellar astrocytoma collected at the time of surgery using microdissection techniques and was analyzed for somatic mutations of the GNAS1 gene. In brief, genomic DNA was amplified from exon 2 to exon 13 of the GNAS1 gene, including intron/exon boundaries using cyaninelabelled primers described previously $[10,11]$. Each PCR mix consisted of $60 \mathrm{ng}$ of DNA, $0.1 \mu M$ of each primer, $1 \times$ PCR buffer, 2.0 $\mathrm{m} M \mathrm{MgCl}_{2}, 200 \mu M \mathrm{dNTPs}$, and $0.75 \mathrm{IU}$ of Taq polymerase (Perkin Elmer) in a total volume of $25 \mu 1$. PCR reactions were performed in a GeneAmp 9700 thermocycler (Perkin-Elmer) at $94^{\circ} \mathrm{C}$ for $30 \mathrm{~s}, 58^{\circ} \mathrm{C}$ for $30 \mathrm{~s}$, and $72^{\circ} \mathrm{C}$ for $1 \mathrm{~min}$ for a total of 35 cycles with an initial denaturation step $\left(95^{\circ} \mathrm{C}\right.$ for $\left.5 \mathrm{~min}\right)$ and a final extension step $\left(72^{\circ} \mathrm{C}\right.$ for $7 \mathrm{~min}$ ). PCR-amplified products were separated on agarose gel, excised, purified with MicroSpin S-200 HR columns (Amersham Pharmacia Biotech) and subjected to cycle-sequencing reactions for 20 cycles using the Thermo Sequenase dye primer cycle sequencing kit (Amersham Pharmacia Biotech). After a denaturation step $\left(94^{\circ} \mathrm{C}\right.$ for $5 \mathrm{~min}$ ) cycle sequencing products were resolved on an automated laser fluorescence sequencer (ALF Express; Amersham Pharmacia Biotech) using 6.5\% Long Ranger gels at $40 \mathrm{~W}(1,000 \mathrm{~V}, 40 \mathrm{~mA})$.

\section{Control Individuals and Polymorphism Analysis}

Using cyanine-labelled primers (exons 7-10: upstream 5'-GCG CTG TGA ACA CCC CAC GTG TCT-3'; downstream 5'-CGC AGG GGG TGG GCG GTC ACT CCA-3') [11], a 711-bp PCR product was amplified. A two-allele polymorphism (C-to-T transition) was detected among the family members $30 \mathrm{bp}$ upstream from the 3'-splice site of intron 7 by nucleotide sequence analysis (fig. 3). The wild-type allele $\left(\mathrm{A}_{1}\right)$ contains two HinF I restriction sites, one of which is eliminated by the C-to-T transition in the mutant allele $\left(\mathrm{A}_{2}\right)$. Restriction endonuclease digestion of the 711-bp PCR product from individuals who were homozygous for the $A_{1}$ allele generated two cyanine-labelled fragments with a length of 121 and $452 \mathrm{bp}$, respectively. In individuals who were heterozygous for the alleles $A_{1} A_{2}$, three cyanine-labelled fragments of 121,259 , and $452 \mathrm{bp}$ were generated. The allele frequency was estimated from the analysis of the polymorphic site in 103 unrelated Caucasians. After HINF I digestion according to the manufacturer's protocol (New England BioLabs), DNA fragments were separated on $6.5 \%$ Long Ranger polyacrylamide gels on an automated laser fluoresence sequencer (ALF; Amersham Pharmacia, Biotech). 


\section{RNA Extraction and RT-PCR}

mRNA was extracted and purified from blood and tumor tissue cells by the use of a QuickPrep Micro mRNA purification kit (Amersham Pharmacia Biotech) and stored at $-80^{\circ} \mathrm{C}$. cDNA was generated with RT-PCR using random hexamer primers supplied by the first-strand cDNA synthesis kit (Amersham Pharmacia Biotech) according to the manufacturer's protocol. The coding region between exon 6 and exon 10 was then amplified from $1.5 \mu \mathrm{l}$ of the cDNA reaction mixture using a sense primer $\left(5^{\prime}\right.$-TCT GTG GGA GGA TGA AGG AGT G-3') and an antisense primer (5'-AGG CGG TTG GTC TGG TTG TC-3'). The PCR was performed in a final volume of $22 \mu \mathrm{l}$ containing $0.18 \mu \mathrm{M}$ of each primer and $0.8 \mathrm{IU}$ of Taq polymerase. The PCR consisted of 35 cycles of $1 \mathrm{~min}$ at $94^{\circ} \mathrm{C}, 1 \mathrm{~min}$ at $58^{\circ} \mathrm{C}$, and $1 \mathrm{~min}$ at $72^{\circ} \mathrm{C}$ with an initial denaturation step of $5 \mathrm{~min}$ at $94^{\circ} \mathrm{C}$ and a final elongation step of $7 \mathrm{~min}$ at $72^{\circ} \mathrm{C}$. The amplified GNASI cDNA fragments were subjected to electrophoresis on an $1 \%$ agarose gel and visualized after ethidium bromide staining. Glyceraldehyde-3-phosphate dehydrogenase specific primers (sense 5'-ACA GTC CAT GCC ATC ACT GCC-3'; antisense 5'-GCC TGC TTC ACC ACC TTC TTG-3') were employed as positive controls under the same PCR conditions mentioned above.

\section{$G_{S \alpha}$ Bioactivity}

The activity of $\mathrm{G}_{\mathrm{S} \alpha}$ protein from erythrocyte membranes of the patients was analyzed in vitro according to the method of Levine et al. [3]. After solubilization and activation of the $\mathrm{G}_{\mathrm{S} \alpha}$ protein, the generation of cyclic adenosine monophosphate was measured by radioimmunoassay using adenylyl cyclase from turkey red cell membranes in the presence of adenosine triphosphate. Results were obtained in triplicate and were expressed as percentage of the mean of healthy controls.

\section{Results}

\section{$G_{S \alpha}$ Bioactivity}

In all 3 AHO patients of the family (index patient, mother, brother) the $\mathrm{G}_{\mathrm{S} \alpha}$ bioactivity was reduced to approximately $50 \%$.

\section{Mutation Analysis}

No mutations were found in genomic DNA within the coding region of exon 2 to exon 13, including intron/exon boundaries, except an intronic C-to-T transition $30 \mathrm{bp}$ from the splice donor site of exon $7(\operatorname{In} 7 \mathrm{sds}+30)$. This polymorphism was found in all AHO patients but not in healthy family members (fig. 3). The allelic frequency of the polymorphism was analyzed with HinF I restriction digestion in genomic DNA of 103 anonymous healthy blood donors, who served as control individuals. In all 206 control alleles the wild-type sequence was detected, thus excluding a common polymorphism.

To evaluate a possible effect on the transcriptional level, RT-PCR was performed between exon 6 and exon 10 which did not reveal any alternatively spliced variants.
Two known polymorphisms within exon 5 and exon 13 of GNAS1 revealed homozygous allele patterns for all 3 affected family members and could, therefore, not be used to analyze for possible exclusive transcription of the wildtype sequence.

As expected, the germline polymorphism in intron 7 was also detected in the genomic DNA of the cerebellar astrocytoma. No other mutations were found in tumor DNA, neither at the two well-known oncogenic mutations sites (Arg 201 and Gln 227) nor within the complete coding region between exon 2 and exon 13 of GNAS1.

\section{Discussion}

AHO is a rare inherited syndrome characterized by a specific phenotype with skeletal abnormalities and, in some cases, PHP. PHP is caused by resistance to PTH resulting from deficiency of the alpha chain of the stimulatory guanine nucleotide binding protein $\left(\mathrm{G}_{\mathrm{S} \alpha}\right)$. Heterozygous inactivating mutations of the GNASl gene, encoding for the $G_{S \alpha}$ protein, have been associated with parathyroid and thyroid hormone resistance in AHO patients $[5,12,13]$. In a series of 8 patients with AHO and PHP IA, GNAS1 mutations were found in half of the cases [14].

GNAS1 is imprinted in a promoter-specific fashion, and PHP IA is virtually always inherited maternally [15], as it was in our case. The patient exhibited the classic phenotype of AHO combined with PHP IA, including a deficient $\mathrm{G}_{\mathrm{S} \alpha}$ bioactivity of $50 \%$. Accordingly, a heterozygously inactivated GNAS1 gene has to be expected at the genomic level. However, no mutations were found in the coding region of GNAS1 despite a reduction of the $\mathrm{G}_{\mathrm{S} \alpha}$ enzyme activity. Nevertheless, an intronic polymorphism was detected which was strictly related to the disease carrier and was not found in nonaffected family members or in 103 control individuals. At the transcriptional level, there was no evidence for abnormal splice variants caused by this polymorphism.

Although a decreased translation efficiency cannot be excluded, it seems to be more likely that the intronic polymorphism is linked with a nondetected mechanism of gene inactivation such as promoter or enhancer alterations or mutations within exon 1 [15]. A potential association of the polymorphism and AHO remains to be evaluated by determining the allele frequency in other $\mathrm{AHO}$ families. We could not exclude that our results included an incidental finding. 
GNAS1 is also known to have an oncogenic potential. Two oncogenic mutation sites (Arg 201 and Gln 227) of the GNAS1 gene have been shown to cause autonomous cyclic adenosine monophosphate production in $43 \%$ of growth hormone secreting human pituitary tumors [9, 16]. Cyclic adenosine monophosphate is an intracellular second messenger and has the ability to stimulate cell growth $[17,18]$. It has been shown that autonomous activity of the Gs protein, that is able to transmit proliferative signals of extracellular hormones, promotes tumor growth by inhibiting the guanosine triphosphatase of the guanosine triphosphate binding subunit of the $\mathrm{G}_{\mathrm{S} \alpha}$ protein [19]. The oncogene was termed gsp and was also found to be mutated in 4 out of $6(66.6 \%)$ ovarian and testicular Leydig cell tumors [8]. In corticotroph adenomas of the pituitary, $g s p$ mutations were found less frequently (2 out of 32 patients) [20].

Previously, a 53-year-old woman with PHP and a cerebellar pilocytic astrocytoma was described [21]. No mo- lecular studies were performed in the patient. In contrast to the young girl presented here, there were no radiological bone abnormalities or evidence of familial transmission. So far, the oncogenic potential of the GNAS1 gene was only described for endocrine tumors, and none out of 29 glioblastomas exhibited alterations of codons 201 and 227 of GNAS1 [9]. DNA analysis of the cerebellar astrocytoma in the present case did not show any mutations of the two gsp mutation sites or within the coding region between exon 2 and exon 13 of GNAS1 apart from the described intronic germline polymorphism. Endocrine tumors, such as growth hormone producing pituitary tumors or ovarian and testicular Leydig cell tumors, are associated with activation of the Gs protein, whereas AHO is combined with a reduced Gs protein activity. This functional discrepancy and the lack of mutations at the gsp mutations sites of GNAS1 in the cerebellar astrocytoma support the notion that the $G_{S \alpha}$ protein is rather not involved in the tumorigenesis of pediatric gliomas.

\section{References}

1 Albright F, Burnett CH, Smith PH, Parson W: Pseudohypoparathyroidism: An example of 'Seabright-Bantam syndrome'. Endocrinology 1942;30:922-932.

2 Farfel Z, Brickman AS, Kaslow HR, Brothers VM, Bourne HR: Defect of receptor-cyclase coupling protein in pseudohypoparathyroidism. N Engl J Med 1980;303:237-242.

3 Levine MA, Downs RW Jr, Singer M, Marx SJ, Aurbach GD, Spiegel AM: Deficient activity of guanine nucleotide regulatory protein in erythrocytes from patients with pseudohypoparathyroidism. Biochem Biophys Res Commun 1980; 94:1319-1324.

4 Conklin BR, Bourne HR: Structural elements of $G$ alpha subunits that interact with $G$ beta gamma, receptors, and effectors. Cell 1993;73: 631-641.

5 Patten JL, Levine MA: Immunochemical analysis of the alpha-subunit of the stimulatory Gprotein of adenylyl cyclase in patients with Albright's hereditary osteodystrophy. J Clin Endocrinol Metab 1990;71:1208-1214.

6 Kozasa T, Itoh H, Tsukamoto T, Kaziro Y: Isolation and characterization of the human Gs alpha gene. Proc Natl Acad Sci USA 1988;85: 2081-2085.

7 Collins RM, Shenker A: McCune-Albright syndrome: New insights. Curr Opin Endocrinol Diabetes 1999;6:119-125.

8 Fragoso MC, Latronico AC, Carvalho FM, Zerbini MC, Marcondes JA, Araujo LM, Lando VS, Frazzatto ET, Mendonca BB, Villares SM: Activating mutation of the stimulatory $\mathrm{G}$ protein (gsp) as a putative cause of ovarian and testicular human stromal Leydig cell tumors. J Clin Endocrinol Metab 1998;83:2074-2078.
9 Lyons J, Landis CA, Harsh G, Vallar L, Grunewald $\mathrm{K}$, Feichtinger $\mathrm{H}$, Duh QY, Clark $\mathrm{OH}$, Kawasaki E, Bourne HR: Two G protein oncogenes in human endocrine tumors. Science 1990;249:655-659.

10 Miric A, Vechio JD, Levine MA: Heterogeneous mutations in the gene encoding the alpha-subunit of the stimulatory $G$ protein of adenylyl cyclase in Albright hereditary osteodystrophy. J Clin Endocrinol Metab 1993;76: 1560-1568.

11 Shapira H, Mouallem M, Shapiro MS, Weisman Y, Farfel Z: Pseudohypoparathyroidism type Ia: Two new heterozygous frameshift mutations in exons 5 and 10 of the Gs alpha gene. Hum Genet 1996;97:73-75.

12 Warner DR, Weinstein LS: A mutation in the heterotrimeric stimulatory guanine nucleotide binding protein alpha-subunit with impaired receptor-mediated activation because of elevated GTPase activity. Proc Natl Acad Sci USA 1999;96:4268-4272.

13 Weinstein LS, Gejman PV, Friedman E, Kadowaki T, Collins RM, Gershon ES, Spiegel AM: Mutations of the Gs alpha-subunit gene in Albright hereditary osteodystrophy detected by denaturing gradient gel electrophoresis. Proc Natl Acad Sci USA 1990;87:8287-8290.

14 Ahmed SF, Dixon PH, Bonthron DT, Stirling HF, Barr DG, Kelnar CJ, Thakker RV: GNAS1 mutational analysis in pseudohypoparathyroidism. Clin Endocrinol (Oxf) 1998;49: 525-531.
15 Hayward BE, Kamiya M, Strain L, Moran V, Campbell R, Hayashizaki Y, Bonthron DT: The human GNAS1 gene is imprinted and encodes distinct paternally and biallelically expressed G proteins. Proc Natl Acad Sci USA 1998;95:10038-10043.

16 Yang I, Park S, Ryu M, Woo J, Kim S, Kim J, Kim Y, Choi Y: Characteristics of gsp-positive growth hormone-secreting pituitary tumors in Korean acromegalic patients. Eur J Endocrinol 1996;134:720-726.

17 Dumont JE, Jauniaux JC, Roger PP: The cyclic AMP-mediated stimulation of cell proliferation. Trends Biochem Sci 1989;14:67-71.

18 Rozengurt E: Early signals in the mitogenic response. Science 1986;234:161-166.

19 Landis CA, Masters SB, Spada A, Pace AM, Bourne HR, Vallar L: GTPase inhibiting mutations activate the alpha chain of Gs and stimulate adenylyl cyclase in human pituitary tumours. Nature 1989;340:692-696.

20 Williamson EA, Ince PG, Harrison D, KendallTaylor P, Harris PE: G-protein mutations in human pituitary adrenocorticotrophic hormone-secreting adenomas. Eur J Clin Invest 1995;25:128-131.

21 Markov LL: Bilateral symmetrical striopallidodentate calcification associated with pseudohypoparathyroidism demonstrated in a patient with cerebellar astrocytoma. Neurosurgery 1991;28:609-612. 